\title{
Decision Management Tools for Trans-Boundary Water Management in Lake Chad Basin
}

\author{
Adeniran Akanni \\ Environmental Planning \& Climate Change Department, Ministry of Environment, Lagos, Nigeria
}

\section{Email address:}

adeniranakanni@yahoo.com

\section{To cite this article:}

Adeniran Akanni. Decision Management Tools for Trans-boundary Water Management in Lake Chad Basin. Journal of Water Resources and Ocean Science. Vol. 7, No. 3, 2018, pp. 49-54. doi: 10.11648/j.wros.20180703.14

Received: August 25, 2018; Accepted: September 14, 2018; Published: October 15, 2018

\begin{abstract}
The Lake Chad basin, one of Africa's oldest river basin has shrank to one-tenth of its original size. The environmental degradation that had occurred in the basin over the years has had direct impact on the livelihood of people in the region. The problem in the Lake Chad Basin has also constituted social risks to populations of the region resulting in accelerating global climate change due to years of unsustainable resource use. The ecological degradation in the basin has further exacerbated conflict with attendant terrorism in the region. Using a coordinated science-policy market place of ideas, an event during the EU-AU Workshop in water-energy-food nexus held in Italy in 2016, a team of scientists and policymakers from both Africa and European Union looked at the reason for the water loss and how to make the solution of inter-basin water transfer proffered practicable. Sustainability tools were recommended in the basin to provide policy advice for decision makers while also developing a nexus framework to enhance future sustainability of the basin. This paper also addresses cooperation among different stakeholders by suggesting new governance pattern and opening up the basin to external collaborators to reverse the declining fortune of Lake Chad basin.
\end{abstract}

Keywords: Lake Chad, Trans- Boundary, Basin, Conflict, Management

\section{Introduction}

Water resources management has been a key scientific and social concern of this century. While reliable access to water still cannot be completely assured globally, large human and socio-economic losses are attributable to the effects of flooding and drought. This, in effect, is intensifying water scarcity, threatening freshwater ecosystems, food security, and increasing water-related diseases and associated impacts on society [1]. The Africa continent seems to be vulnerable to these impacts, hence the need for international and national attention over water-related risks [2]). As a response to these challenges, nations now see the need to address the issues in a coordinated manner through trans- boundary basin management. The Lake Chad Basin Commission in Africa typifies an attempt to address these problems at regional scale.

Lake Chad is located in the far west of Chad, bordering on north-eastern Nigeria (Figure 1). The Chari River, fed by its tributary the Logone, provides over $90 \%$ of Lake Chad's water, with a small amount coming from the Yobe River in
Nigeria/Niger.

According to Fort Lammy Convention which set up the basin, member States are, required to abstain from measures likely to alter the water budget, water quality, integrated water resources management, or water access by other member States. The Convention also recognizes the right of member states to plan projects within the "Conventional Basin" in consultation with the LCBC [3].

The LCBC has a broad mandate including, inter alia, provisions related to prior notification, the monitoring of progress of studies and works related to water resources, and the authority to examine complaints and contribute to the resolution of conflicts and differences of opinion among member States [4].

The impact assessment report of Lake Chad Basin [6] noted that the demand for water for irrigation has increased fourfold due to fluctuations of the basin in response to climate cycles leading to dramatic environmental changes. In 1963, the lake surface covered 25,000 Km. Today, it covers $1,350 \mathrm{Km}$ (Figure 2), which represents about 1,750\% reduction in surface area within 54 years and annual loss in 
area of approximately $438 \mathrm{Km}$. The basin's present annual evapotranspiration has been estimated at $2000 \mathrm{~mm}$ [7]. This can be another contributor to changes in surface area of the Lake, albeit minimally. If this trend continues, Lake Chad will completely disappear in 2020- which is three years from now. Vegetation in the Northern part has also disappeared apparently due to anthropogenic factors like humans extracting wood biomass for fuel and, as a result of this, sand dunes have begun to form on the dry lakebed [8].

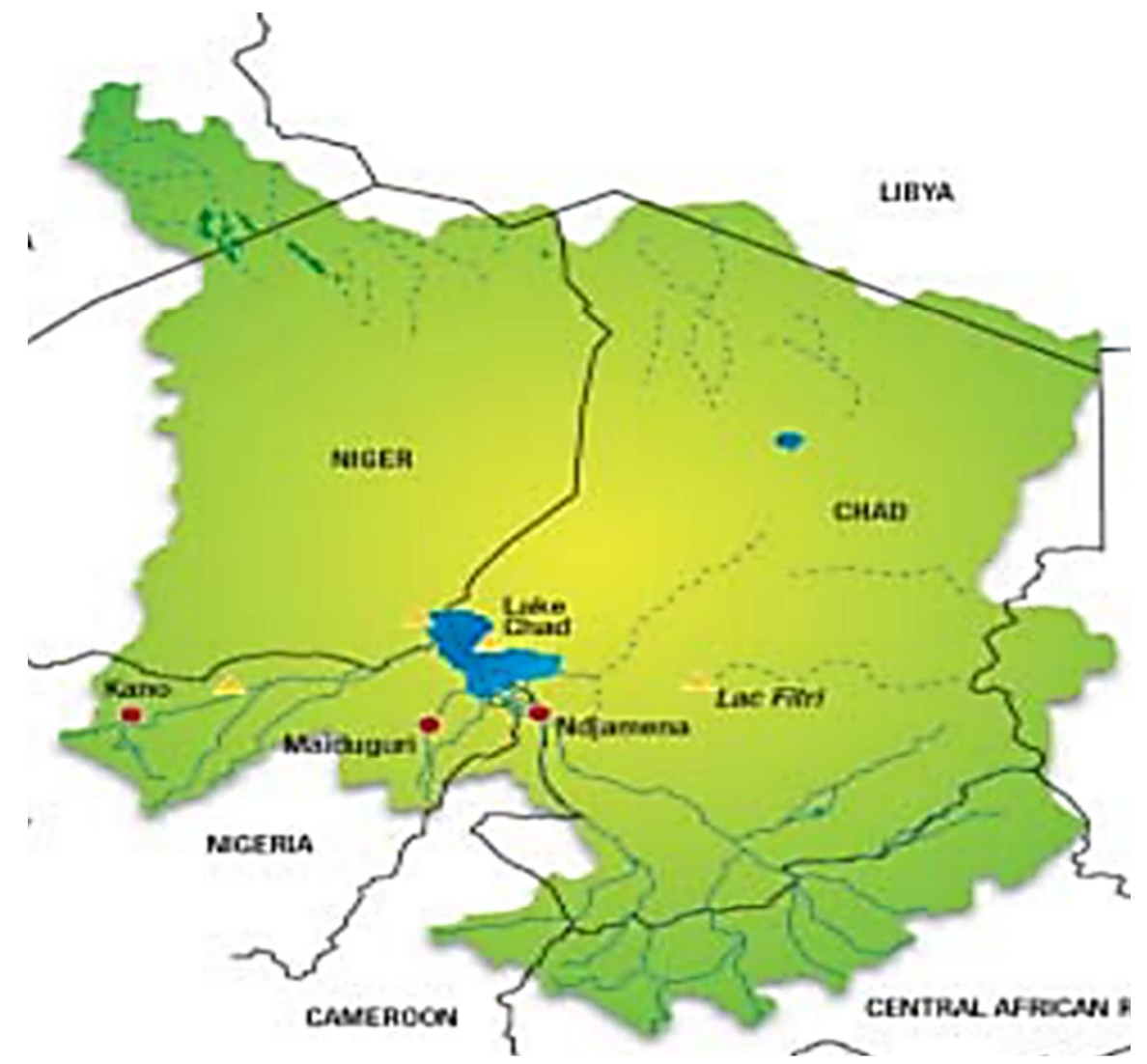

Figure 1. The Map of Lake Chad Basin Region [11].
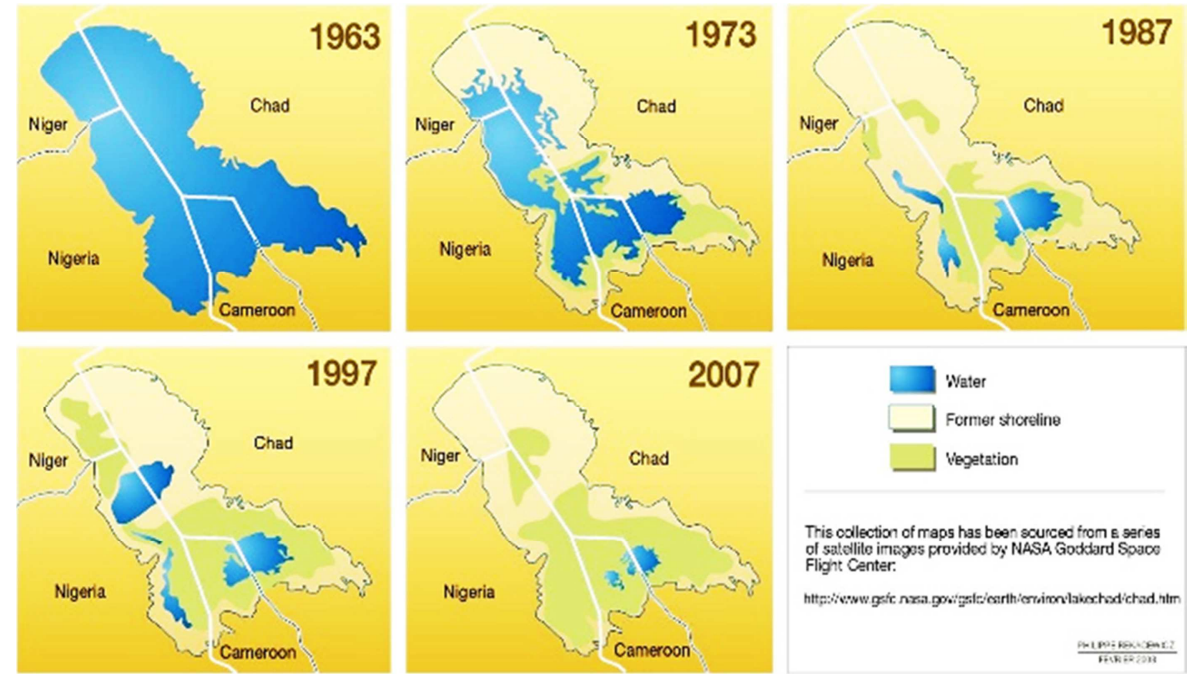

Figure 2. Shrinking Lake Chad Basin [5].

Furthermore, increase population in the basin and construction of dams have been identified as notable contributors to its recent shrinkage. According to UNEP, Population has increased considerably over the last 50 years to about 37 million in the basin in 2003[5]). Population increase will likely result in increased water demands (domestic, agricultural, etc.) and thus more stress on the water resources (surface and groundwater) of the basin

This environmental degradation had a direct impact on the livelihood of people in the basin. Pastureland has only $66 \%$ 
of the carrying capacity they had prior to the drought. Economic activities such as fishing, livestock rearing and farming have been adversely affected and many people have had to migrate as environmental refugees [6]. The increasing competition for resources and conflict amongst farmers, herdsmen and fishermen has led to increase tension in the region. The attendant socio-economic problem as a result of limited resources has made the regions where this transboundary resources is located to be fragile in nature [9].

The Water, Energy and climate nexus is a complex and multi-dimensional policy and scientific issue, covering both sustainability and resilience aspects. It also deserves an integrated policy approach.

The paper looks at the current challenges facing the Lake Chad basin which has shared the concept of governance based on regionalism) as it relates to transnational cooperation to achieve a common goal or resolve a shared problem which in this case is water in the region.

Using a coordinated a science-policy market place event during the EU-AU market place of ideas in water-energyfood nexus in Ispra Italy, the event is part of achieving the 2063 Africa Union vision in the framework of AU-EU partnership. This paper deliberated on the reasons for the water loss in the basin as well as suggesting a possible solution to supply water from the Congo Basin via a canal, 2,400 kilometres long to recharge the basin. Other issues examined were major political, technical, and economic challenges that have to be overcome to make this practical. Furthermore, tools of sustainability that could be deployed in the basin to provide policy advice for decision makers whilst developing a framework for reducing conflict and also enhance cooperation among the players to reverse the declining fortune of Lake Chad basin by building a reliable basis for decision making through new governance approach were examined as well as recommendation to move the basin forward.

\section{Methods}

The marketplace of Ideas event organised as part of joint Africa-EU strategy for improving practices in better integrating evidence into policy-making in the Water-EnergyFood Security nexus organised at the European Commission's Joint Research Centre site in Ispra, Italy from 31 st August to $2^{\text {nd }}$ September 2016 provided the forum for deliberating on the Water management decision tools for trans boundary water management using Lake Chad Basin as a case study which the Author coordinated.The rationale was to deepen the art of evidence based decision making and improving its impact on policy decisions in the field of sustainable development. The event further support this challenging task by helping scientists and policymakers, from Europe and Africa to work on the nexus and to consider and understand better the constraints and demands from both the scientific and the policy-making perspective. It was a participatory modelling approach in which participants of about 6 addressed the policy challenge and the evidence needed - e.g. data, analysis, assessments - to inform a policy decision addressing the challenge of shrinking Lake Chad basin and the proposal of inter- basin water transfer the Congo Basin via a canal 2,400 kilometres (1,500 mi) as well as major political, technical, and economic challenges that would have to be overcome to make this practical. The group comprise both scientists and policy officers from Africa and EU representing Ministry of Environment in Nigeria, University of Sussex, UK, Greek Ministry of Environment, United Nations Economic Commission for Africa(UNECA), German Ministry of Economic Cooperation and Development as well as from University of Barcelona in Spain., This group then worked together on this idea for the session and came up with an output in which the author further developed into a policy paper.

\section{Results and Discussion}

Participants of the Marketplace ideas event agreed that more data is needed to inform decision support in terms of modelling on Lake Chad basin area. Furthermore, climatological data as well as surface and ground water dynamics of the basin should be studied.

Regarding the planned trans-basin water transfer to recharge the basin, there is need for feasibility study covering environmental and health impacts, cost benefit for the people in the area, socio-economic impacts as well as political acceptance from the surrounding countries. The proposal submitted for Transaqua project for water transfer from Congo basin by Bonfica Inc. as diagrammed in figure 3 below was widely accepted.

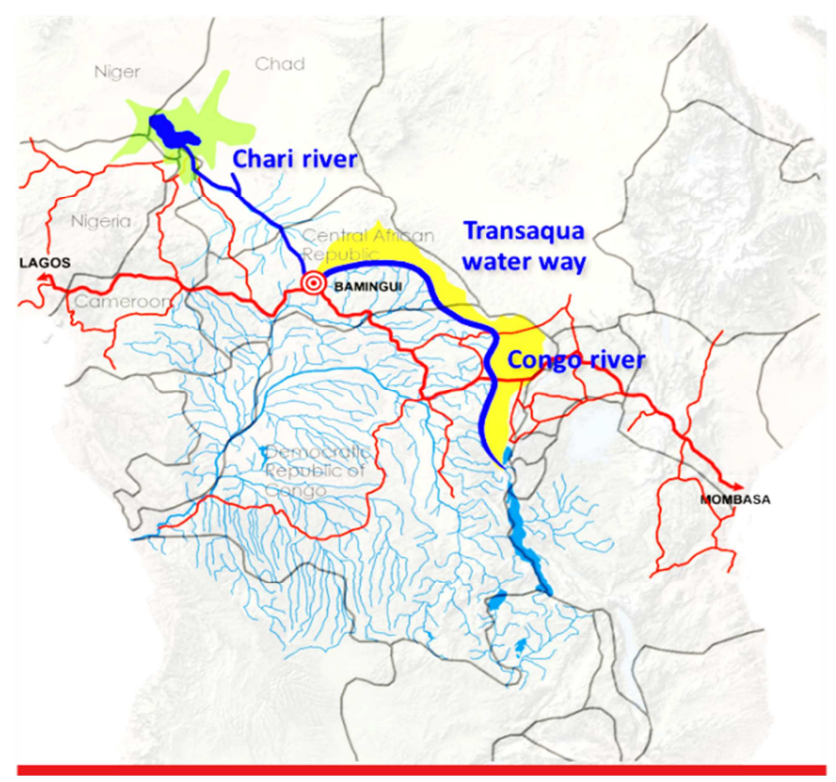

Figure 3. Proposed Transaqua project route [10].

The idea of Trans aqua project is to transfer water from the Congo River basin to the Chad Lake in Sahel district. By this, the water volume of the Congo River pours into the Ocean every year, could contribute by about $8 \%$ of this 
capacity to Lake Chad.

The realization of a waterway which could be navigable, was considered. Also conceived is a waterway that will be fed with water from the Congo River tributaries located on the North East basin. Thus the entire way which is estimated at $2400 \mathrm{~km}$ starting in the DRC which crosses the Central African territory and the watershed before pouring into the CHARI river is considered as the main source of water in Lake Chad [10].

Although, the Trans aqua inter-basin water transfer project appears to be the primary choice for replenishing the Lake Chad waters and may be the largest trans- boundary water transfer project in Africa. However, for this to work to come to reality, major political challenges has to be overcome since this has been the key challenge delaying the inter-basin water transfer to Lake Chad [12].

The geological aquifer of Lake Chad basin belongs to Nubian Sandstone Aquifer System (NSAS) which includes the countries of Chad, Egypt, Libyan and Sudan. The geological setting of the aquifer consist of Quaternary sandyclayey sediments of different depositional times and environments and thicknesses varying from $200 \mathrm{~m}$ to the north of the Lake Chad to some centimeters on the borders [13].

The sands of the aquifer is being underlain by upper Pliocene clays with a mean thickness of approximately 280 $\mathrm{m}[14]$.

The Upper aquifer of Lake Chad basin has been described as unconfined and semi-confined while the Middle and Lower aquifers are confined [15].

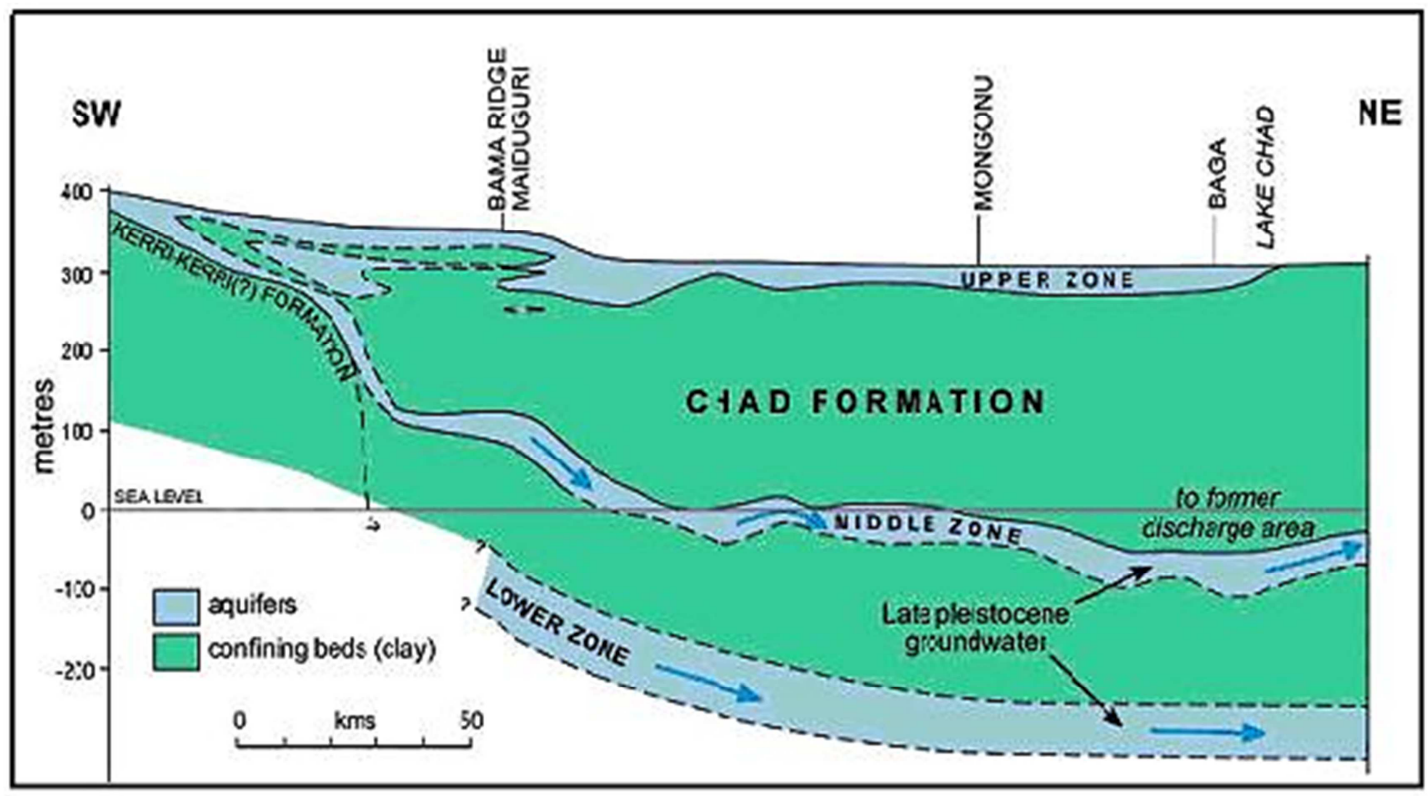

Figure 4. A Cross-section showing the geology of Lake Chad Aquifer [15].

There is a need for a detailed study of the underground water recharge system of the aquifer of Lake Chad basin considering the planned interbasin water transfer. The Managed Aquifer recharge (MAR) study is a veritable option because of the potential for the restoration of underground water aquifer. Furthermore, the development of an innovative web-based Decision Support System for Water Sustainability under a Changing Climate (INOWAS) to support the MAR scheme by a research group in Germany, [16], on the planning, management and optimisation of managed aquifer recharge applications will be desirable. Also modelling the underground water parameters in the basin could be achieved using a hydrologic model, Mudflow, for simulating and predicting groundwater conditions and groundwater/surfacewater interactions [17].

Other soft options considered include water conservation initiatives, reduction of water abstraction from the basin through monitoring and legislation as well as exploring the potential of ongoing Africa great green wall initiatives. Overall, sustainable management of the basin could be achieved through modelling a nexus approach of health-energy-food and biodiversity according to the figure 5 below:

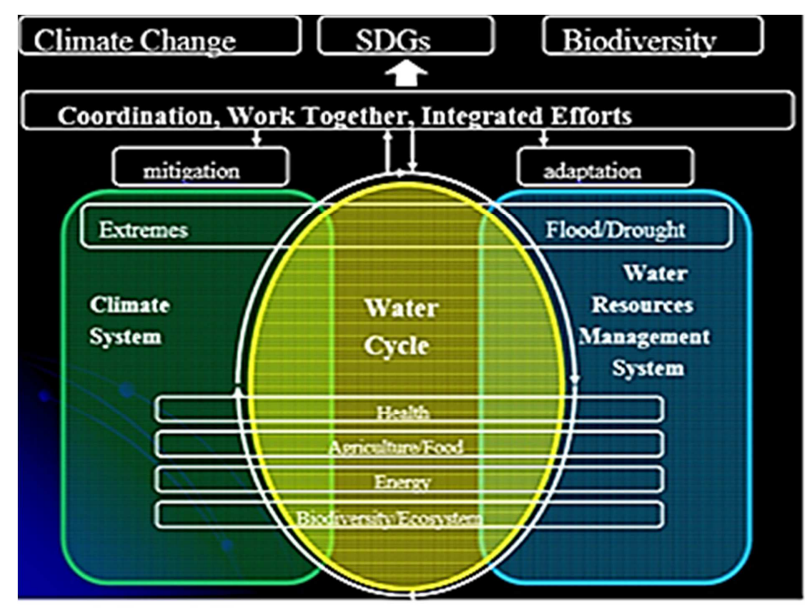

Figure 5. Health-energy-food-biodiversity nexus approach [1].

The framework proposed is an Integrated, dynamic, 
multidisciplinary and multi-stakeholder approach to manage the Lake Chad Basin. It seeks to integrate health of the basin, agriculture /land use change, energy and biodiversity issue in dealing with the climatic changes that pose a threat to the basin and ensure sustainable development.

Tools of sustainability as well as integrated framework discussed in Figure 5 above should be deployed in the basin to provide policy advice for decision makers whilst developing a framework for reducing conflict and also enhance cooperation among the players to reverse the declining fortune of Lake Chad basin .This paper supports the inter-basin water transfer from the Congo basin. However, there is need for hydrological justification of the plan especially through ground water assessment using Mudflow described above before implementation of Managed Aquifer Recharge(MAR).This scheme could form a reliable basis for decision making in river and water resource management of Lake Chad Basin. Currently, precipitation in the basin varies from $1,400 \mathrm{~mm}$ in the south to less than $50 \mathrm{~mm}$ in the north with $50 \%$ of the basin getting less than $400 \mathrm{~mm} /$ year while the mean annual temperature for the whole basin varies between $26^{\circ} \mathrm{C}$ and $29^{\circ} \mathrm{C}$ with average maxima between $33^{\circ} \mathrm{C}$ and $37^{\circ} \mathrm{C}$ and average minima between $18^{\circ} \mathrm{C}$ and $22^{\circ} \mathrm{C}[14$, $18,19]$. Recently an increase in monthly rainfall during the 1990 decade has been attributed to an increase in the intensity of localised rainfall. [20]. Furthermore, the increase in the rainfall trends in the Sudano-Sahel zones of Nigeria has had impacts on the frequent floods observed in Lake Chad area recently [21].The increase in rainfall in the Lake Chad which was attributed to increase in the rising levels of greenhouse gases (GHGs) [22] has not led to concomitant increase in the recovery rate of the basin [23].

\section{Conclusions}

There is need for numerical weather forecasting data that will be integrated into future scenario modelling of extreme events to give information to decision makers and thus help them prepare contingency measures for extreme events in future management of the basin.

In adopting a strategy to reverse the current fortunes of the basin, a participatory science based approach to decision making is needed through data sharing among the riparian countries.

Destruction of biodiversity like trees in the Lake Chad Basin due to human population growth also contributed to the problem of the basin. Working back to back by planting trees is also an agro forestry technique which could improve the hydrology of the Basin with the tree helping to hold water and also prevent erosion. This is where the Great Green Wall (GGW) initiative going on in the area comes handy. Although, the GGW was conceived to stop desertification and erosion, the potential of this wall to protect water in the Lake Chad basin need to be studied and explored.

The regionalism approach of government adopted by member countries of the Lake Chad Basin Commission also needs revisiting. The member countries need to open to other new ideas from outsiders with considerable knowledge to improve the Basin management hence the need to develop new governance approach. Network approach of governance is a veritable option. This external support is already adopted in terms of cooperation forged between Lake Chad member countries and external stakeholders in tackling the terrorism caused by Boko Haram. This type of approach is also needed in tackling the challenge of management of the basin through multi-stakeholder participation to form a vision of harmonious living with nature to improve the resilience of socio-ecological landscape like the Lake Chad basin through a concept of "Satoyama". This apart from exploring new form of co-management system, it aims to secure diverse ecosystem services and through rational use of natural resources contribute to enhanced socio-economics of the region.

The strategic partnership formed between the African and European scientists and policy makers in developing this paper could be further strengthened in developing research themes identified in this paper and joint call by AU-EU for funding explored to put up an initiative to support the LCB in realizing the overall Africa water vision which is to have an Africa where there is equitable and sustainable use and management of water resources for poverty alleviation, socio-economic development, regional cooperation and the environment.

\section{References}

[1] GEOSS Africa Water Cycle Coordination Initiative- AWCCI (2010). Weblink:

www.earthobservations.org/.../1st_AWC_Symposi.

[2] United Nations- Millenium Development Goals(MDG)(2002). Weblink: http://www.un.org/millenniumgoals.

[3] Oyebande L (1997) .Integrated management of the Lake Chad Basin in Nigeria. Preparatory Assistance Report, UNDP/GEF.

[4] (5)Global Environmental Facility (GEF). Report on Lake Chad Basin (2003) .Weblink: www.thegef.org/gef/.../Regional__Lake_Chad_Basin_Ecosystem.p̄pdf.

[5] (16)UNEP (2004). Fortnam, M.P., Oguntola, J.A. (Eds.), Lake Chad Basin, GIWA Regional Assessment 43, University of Kalmar, Sweden, 129 p. Aslo available at: http://www.giwa.net/areas/reports/r43/giwa_regional_assessm ent_43.pdf.

[6] Impact Assessment Inc (IAI) (2006) Environmental and Social Risk Assessment in the Lake Chad Basin. A report submitted to LCBC.

[7] Olivry, J. C., Chouret, A., Vuillaume, G., Lemoalle, J. \& Bricquet, J. P. (1996) Hydrologie du Lac Tchad. Monographie hydrologique $\mathrm{n}^{\circ} 12$, ORSTOM edn., Paris, France.

[8] Mohammed Bila (2011). Brief on Lake Chad Basin. PPt. presentation at the joint workshop on Earth Observation Capacity Development for IWRM at River Basins in Africa held in Nairobi, Kenya. 
[9] Jauro, A.B., 2007. Socio-economic issues and conflict resolution in water resources use. A paper presented at a Regional Roundtable on Sustainable Development of the Lake Chad Basin, organized by DTCA at the University of Maiduguri.

[10] Bonfica Inc.(2018). Presentation by Bonfica Inc. at the International Conference on Lake Chad Basin in February, 2018, Abuja, Nigeria

[11] World Wildlife Fund (WWF) 2010.Managing Rivers WiselyLake Chad. Web link: assets.panda.org/downloads/mrwlakechadcasestudy.pdf.

[12] Magrin Geraud(2016).The disappearance of Lake Chad :history of a myth.Journal of Political Ecology 23:204222 .

[13] (3)Djoret D (2000) Étude de la recharge de la nappe du Chari Baguirmi (Tchad) par les méthodes chimiques et isotopiques. Dr-Thesis at the Université d'Avignon et des pays de Vaucluse, France.

[14] (14)Schneider JL, Wolff JP (1992) Carte géologique et cartes hydrogéologiques à 1/1,500,000 de la Républic du Tchad : Mémoire explicatif (Geologic and Hydrolgeological Maps of the Chad Republic in a $1: 500000$ scale: explanatory memorandum).

[15] Goni, I.B., Kachallah, M. and Aji, M.M., 2000. Another look at the peizometric head declines in Middle zone aquifer of the Chad Formation in the Southwestern Chad basin. Borno J. Geology, 1\&2 (2), Pp. 51-64.

[16] (13)Ringleb, J., Sallwey, J., Stefan, C. (2016): Assessment of Managed Aquifer Recharge through Modeling-A Review. Water, 8(12): 579. doi:10.3390/w8120579.
[17] (4)Harbaugh, A.W., 2005, MODFLOW-2005, The U.S. Geological Survey modular ground-water model - the Ground-Water Flow Process (TM 6-A16).

[18] (4)Eberschweiler CH (1993) Monitoring and Management of Groundwater Resources in the Lake Chad Basin. Final Report Project R 35 985. BRGM with funding from Fonds d'aide et de Coopération de la République Française Convention $\mathrm{N}^{\circ}$ 98/C88/ITE.

[19] Ngatcha BN, Mudry JE, Aranyossy JF, Naah E, Sarrot Reynault J (2007) Apport de la géologie, de l'hydrogéologie et des isotopes de l'environnement à la connaissance des « nappes en creux » du Grand Yaéré (nord Cameroun). Revue des Sciences de l'Eau 20 (1) (2007) 29-43. ISSN : 1718-8598.

[20] Panthou G, Vischel P, Lebel T. 2014. Short Communication: Recent trends in the regime of extreme rainfall in the Central sahel. Int J Climatol. 34: 3998 - 4006.

[21] Ifabiyi, IP, Ojoye S. 2013. Rainfall Trends in the SudanoSahelian Ecological Zone of Nigeria. Earth Sci ResJ. 2(2).

[22] (4) Dong B, Sutton R. 2015. Dominant role of greenhouse-gas forcing in the recovery of Sahel rainfall. Nat. Clim Chang. doi: 10.1038/NCLIMATE2664.

[23] (11) Okonkwo C, Demoz B, Sakai R, Ichoku C, Anarado C, Adegoke J, Amadou A, Abdullah SI. 2015. Combined Effect of El Niño Southern Oscillation and Atlantic Multidecadal Oscillation on Lake Chad level variability. Cogent Geoscience. 1: 1117829 